\title{
VADICO, Luiz. Filmes de Cristo, oito aproximações. São Paulo: a lápis, 2009, 232p.
}

Joelma Aparecida dos Santos Xavier *

Luiz Vadico, historiador, escritor e professor do Mestrado em Comunicação da Universidade Anhembi Morumbi de São Paulo, em seu livro, Filmes de Cristo, oito aproximações, procura mostrar a existência de uma área chamada Cristologia Fílmica, que propõe uma técnica facilitando o trabalho da apreciação fílmica. Luiz Vadico esclarece através de exemplos como o personagem mais importante da era cristã deixou de ser apenas um ícone sagrado e ganhou várias facetas ao migrar para o cinema. Vadico examinou a produção cinematográfica cristológica entre 1895 e 2004. São 21 os principais filmes sobre a vida de Cristo, e no imaginário das pessoas hoje não há uma imagem unívoca de quem seja Jesus. Dividido em oito artigos/capítulos, o livro não busca questionar as releituras dos cineastras, e sim compreendê-las a fim de se chegar à percepção que as pessoas têm de Cristo através da imagem que o cinema passa.

No capítulo "Jesus Film - uma breve introdução ao estudo dos filmes de Cristo", são dadas as primeiras noções sobre filmes de Cristo, que contam parcialmente ou totalmente a história de Jesus Cristo e que podem ser classificados como filme religioso ou épico bíblico. La Passion (1897) dos irmãos Lumiére é a primeira produção do gênero épico bíblico e é uma produção barata, com poucos recursos, grandes cenários pintados, mas um investimento seguro para o produtor. Já Os dez mandamentos (1923/1956) e $O$ manto sagrado (1953) são os primeiros com inovações tecnológicas no cinema. Além disso, atores populares eram os que faziam os papéis mais importantes.

Este gênero épico pode ser classificado como: épicos do velho testamento (Sansão e Dalila - 1949, O filho do pródigo - 1955, A estória de Rute - 1960), épicos romanocristãos ( $O$ sinal da Cruz - 1932, Salomé - 1953, Barrabás - 1962) e filmes de Cristo (O

\footnotetext{
* Mestranda em Ciências da Religião pela Pontifícia Universidade Católica de Minas Gerais. Pedagoga, tem experiência profissional com a área da Educação e Prática Pedagógica. Trabalha com aulas de Ensino Religioso em uma escola estadual de Ouro Preto. País de origem: Brasil. E-mail: joelmaambiental@yahoo.com.br
} 
rei dos reis - 1927, Da manjedoura à cruz - 1912, Golgata - 1953, entre outros). Para analisar essa produção, William Telford sugere que se observe a forma do filme, as fontes, o contexto ideológico, social e o estilo, além da caracterização da imagem física e emocional de Jesus. Para isso, é preciso uma qualidade hermenêutica do pesquisador.

Já no capítulo "Cristologia fílmica - subsídios teórico-metodológicos para a análise da produção de imagens Cristológicas geradas no cinema e na TV”, há inferência à Cristologia (campo da Teologia que estuda os títulos e imagens de Jesus). A metodologia sugerida de pesquisa e análise leva em consideração que desde a sua origem, os filmes já estão determinados por um fundamento religioso. O teólogo Oscar Cullman esclarece que ao fazer uma profissão de fé, está se aceitando tudo relacionado a esta determinada profissão de fé. Quer dizer, não é só aceitar um Cristo hipotético, mas tudo relacionado à sua vida e à sua ação em vida. Entre os critérios e métodos utilizados para a análise estão: o texto base, a observação do fictício, o conteúdo imagético das cenas versus o conteúdo literal dos evangelhos, as afirmações verbais encontradas na diégese, a escolha dos atores, a psicologia das personagens, a opinião do cineastra, a comparação entre o filme analisado e aqueles que o antecederam, o sentido do filme como um todo, o contexto histórico e social da produção, a recepção do filme por seus contemporâneos e as imagens cristológicas estabelecidas pelo cinema. Para isso, é necessário pensar nas imagens elaboradas, observar como são aceitas, dialogar com elas e estabelecer um parâmetro crítico que possibilite uma nova forma de Cristologia pessoal a respeito de Jesus Cristo.

No capítulo "O corpo de Cristo no cinema",Vadico faz uma reflexão sobre a representação do corpo de Jesus a partir da observação direta e análise de cerca de trinta filmes em que o corpo aparece representado. $\mathrm{O}$ autor se detém à comparação descritiva, observando os significados histórico-culturais que os corpos assumidos por Jesus guardavam em si.

O capítulo "Um repertório de imagens para os primeiros filmes de Cristo" é uma tentativa de estabelecer a origem e formação da narrativa da vida de Jesus. Pensa-se aqui em uma divisão sobre os filmes de Cristo em três períodos: o chamado primeiro cinema, o chamado não narrativo e a crescente narrativização. Os primeiros filmes possuíam uma liberdade de montagem, eram compostos de quadros separados. Era o levantamento das imagens da narrativa bíblica incorporadas a outras informações de outros historiadores que 
estabelecia uma linearidade de fatos para a história da vida de Jesus. Ao se entender a existência dessas imagens e sua narratividade no primeiro cinema, compreende-se como as produções cinematográficas posteriores se alteraram ou se mantiveram ao longo do século XX.

No capítulo "Os filmes de Cristo no Brasil - a recepção como fator de influência estilística”, há a necessidade de entender o porquê de quase não existirem filmes brasileiros sobre Jesus Cristo em um país que é praticamente cristão. Filmes que podem contribuir para uma compreensão maior da religiosidade popular muito presente no Brasil. Neste capítulo, há diversos fatos narrados esclarecedores que explicam o motivo pelo qual quase não há filmes de Cristo no Brasil. Além dos episódios narrados, há o fato de terem sido produzidos por grandes empresas internacionais, lenta distribuição destes filmes no mercado interno e sua difusão em um país imenso. Cabe ressaltar que nos centros urbanos durante a Semana Santa, os mesmos filmes eram repetidos como mais um momento de devoção religiosa.

Já no capítulo "O que diz a 'Voz de Deus'? - especificidades do documentário religioso" há uma nova tentativa de aproximação teórica, só que em forma de documentário. É uma Teologia que Vadico chama de "propaganda". Clive Marsh distingue fala sobre Deus e fala de Deus. Na primeira, basta escrever, pensar sobre Deus e está se fazendo teologia. Já na segunda, estão as diversas interpretações dos textos religiosos que tratam de direcionar a vida dos fiéis no sentido geral de cada religião. Vadico esclarece que, diante de um documentário religioso, não se pode perder de vista a teologia envolvida em sua produção, e que boa parte desses documentários não guarda preocupação com uma teoria ou prática mais precisas.

Em "Um filme ou dois? - A Paixão de Cristo de Lumière", a principal contribuição é estabelecer a existência de dois filmes sobre os quais muitos pensavam tratar-se de apenas um. É outro exemplo de como abordar o tema da vida de Jesus pode ser proveitoso para o estabelecimento de novas descobertas. É através da comparação entre as diversas narrativas e alguns dados investigativos que se consegue fazer a distinção.

No último capítulo "O rei dos reis - uma teologia da luz", a principal preocupação é verificar o tipo de teologia ora da luz, ora da luz do cinema, ora da luz de Deus no cinema proposta ao longo do filme. O filme apresenta tanto a teologia das imagens como a do 
material cinematográfico. Este é, segundo Vadico, o mais conhecido filme de Cristo produzido no período do cinema mudo. Resume diversas qualidades que renovam o gênero e o uso distinto dos textos evangélicos.

Vadico busca, portanto, em todos esses capítulos que compõem seu livro Filmes de Cristo, oito aproximações, construir conhecimento sobre o objeto Jesus Cristo a fim de provocar novas questões, novas pesquisas e possibilitar o surgimento de novas respostas. Ao propor esta área de estudo chamada Cristologia Fílmica, mostra-se a fonte de novas representações da imagem de Jesus construídas ao longo do século XX, distanciadas ou não do seu significado transcendental. O cinema fez com que um dos homens mais importante da cultura ocidental deixasse de ser exclusividade dos religiosos. 